\title{
Application of selected marketing and logistics methods in the Czech Republic
}

\author{
Pavel Taraba ${ }^{1}$, Tereza Belantová $^{2}$ \\ ${ }^{1}$ Tomas Bata University in Zlin, Faculty of Logistics and Crisis Management, Studentské nám. 1532,68601 \\ Uherské Hradiště, Czech Republic \\ ${ }^{2}$ Tomas Bata University in Zlin, Faculty of Management and Economics, Mostní 5139, 76001 Zlín, Czech Republic
}

\begin{abstract}
The main aim of the paper is to analyze the level of application of selected marketing and logistics methods in different types of companies. The result of the analysis is a description of the current situation in companies operating in the Czech Republic. In the first stage, relevant information sources from the field of logistics and marketing were analyzed. Data collection was carried out in the form of a questionnaire survey in the second stage. In the third stage, the data were processed, and the results were interpreted using descriptive statistics methods. At the end of the paper, the results and the identified limits are formulated which must be taken into account in their interpretation.
\end{abstract}

\section{Introduction}

The application of marketing methods could be observed in the Czech Republic mainly with the transition to market economy conditions after 1989. Companies realized that suitably reaching potential customers could give them a competitive advantage in a fast-growing market. On the other hand, the leaders of the company management became acquainted with the basic principles of marketing (customer interest, analysis of competition, use of elements of the marketing mix - 4P) [1] only gradually. Savitt [2] considered the minimal knowledge of the management of marketing companies as the main brake on the development of marketing: experiences of top-management under the socialist system form of the way they approach marketing. Today, while the leadership of organizations is familiar with the basic principles of marketing as formulated by e. g., Kotler and Amstrong [3], however, they are losing their effect, and it is increasingly challenging to reach existing or potential customers. Alternative methods (word-ofmouth, product placement, guerilla marketing, mobile marketing, event marketing, and social marketing) are also at the forefront [4] to reach the customers of the product they offer. In recent years, even these alternative methods are no longer sufficient. Hence, companies are looking for ways to increase customer value and to use other forms such as being able to differentiate themselves from their competitors and maintain their competitive advantage in a highly turbulent market. In recent years, we have seen the growing importance of logistics not only in the world but also in the Czech Republic, which is becoming an essential logistics hub not only in Central Europe. One of the main advantages is its geographical position, but the advantageous position without emphasis on analyzing logistical processes, methods of analyzing material flows, and other methods used in logistics management would not be enough.

Successful companies realize that it is not possible to achieve a lasting competitive advantage only through the increased performance of individual departments of the organization, but it is the aim of cooperation of all departments including marketing and logistics.

The article responds to the need to analyze the level of use of marketing and logistics methods as one of the factors of competitiveness of companies in the Czech Republic. The main aim of the paper is to analyze the level of application of selected marketing and logistics methods in different types of companies.

Based on the first stage, the aim of which was to analyze relevant information sources in the field of marketing was selected marketing methods which were subsequently included in the questionnaire:

a) Methods of marketing mix 4P (product, price, place, promotion) [3],

b) Methods of the marketing mix from the perspective of customer 4C (customer value, cost, convenience, communication) [5]

c) Customer Relationship Management (CRM) (an interactive process aimed at achieving an optimal balance between company investment and customer satisfaction) [6]

d) Analysis of marketing environment (analysis of marketing macro-environment, analysis of marketing micro-environment) [1]

\footnotetext{
* Corresponding author: taraba@utb.cz
} 
e) Competition analysis (identification of five forces, a competing company, identification of competitors' goals, identification of competition strategies) [7], [8]

The given methods are also used to interpret the results. (Figure 1)

Based on the first stage, the aim of which was to analyze relevant information sources in the field of logistics was selected logistics methods which were subsequently included in the questionnaire:

a) Methods of analysis of logistic processes or methods of material flow planning (System Analysis, ABC Analysis, Value Analysis, Cost Analysis) e.g., [9]

b) Methods for analyzing the use of workers (e.g., time and spatial imaging, capacity calculations, assign tasks, assignment algorithms) e.g., [10]

c) Methods of material control processes e.g., [11]

d) JUST - IN - TIME, Kanban [12]

e) Methods of operational analysis (e.g., linear programming, the theory of mass service) e.g., [13]

The given methods are also used to interpret the results. (Figure 2)

The concept of marketing logistics according to Christopher and Peck [14] is based on the combination of principles used in marketing and logistics. The combination of these two areas with an emphasis on satisfying the customer's needs by providing added value to current and potential customers is an essential element of the company's sustainable prosperity.

\section{Research design and Methodology}

The survey was carried out in three stages, which took place from December 2018 to March 2019. The first stage, which was to analyze relevant information sources in the field of logistics and marketing, took place during December. Czech, as well as foreign monographs and databases Scopus, Web of Science, ProQuest and Google Scholar, were used as the primary sources of information. The second stage, which was aimed at collecting data on companies operating in the Czech Republic, was conducted in the form of a questionnaire survey between January and February 2019. The questionnaire was created based on the results of the first stage and was distributed by e-mail. The questionnaire survey was used to analyze the level of use of selected marketing and logistics methods in various types of companies. A 5-point scale was used (1 - very high application level - 5 very low application level) where individual respondents were to determine the level of application of selected methods in the organizations they operate. Subsequently, the Average scale value (Asv) was calculated for each method analyzed. Formula 1 was used to calculate it:

$\overline{A s v}=\frac{\sum_{i=1}^{5} i \times h_{i}}{5}$
The research set consisted of 120 respondents). These respondents were selected on a random basis. The number of received questionnaires was 31 , i.e., the return rate was 25.83\%. (According to ownership: Czech $67.74 \%$, European $16.13 \%$, World 16.13\%; according to number of employees: Large 51.61\%. SME 48.39\%) In the third stage, which took place in March 2019, the data were processed, and the results were interpreted using descriptive statistics.

\section{Results}

Companies have different types of organizational structures. Within their definition, they have or do not have a separate marketing or logistics department. (Table 1) Often, marketing activities are carried out within the scope of the company's sales department. Similarly, in some organizations, a separate logistics department is defined within the organizational structure, and on the other hand in other companies, the individual logistics operations are performed within the scope of different company departments.

Table 1. Marketing and Logistics department. [authors].

\begin{tabular}{rrrrrr}
\hline \multicolumn{3}{c}{ Marketing department } & \multicolumn{3}{c}{ Logistics department } \\
\hline & Frequency & Percent & & Frequency & Percent \\
Yes & 17 & $54.84 \%$ & Yes & 17 & $54.84 \%$ \\
No & 14 & $45.16 \%$ & No & 14 & $45.16 \%$ \\
\hline
\end{tabular}

At present, the application of the concept of marketing logistics is not deliberate, but it is the result of the decision of the company management on the type and concrete form of the organizational structure. This statement could be confirmed by the consistent representation of the companies in the research carried out by the marketing department and the logistics department (Table 1).

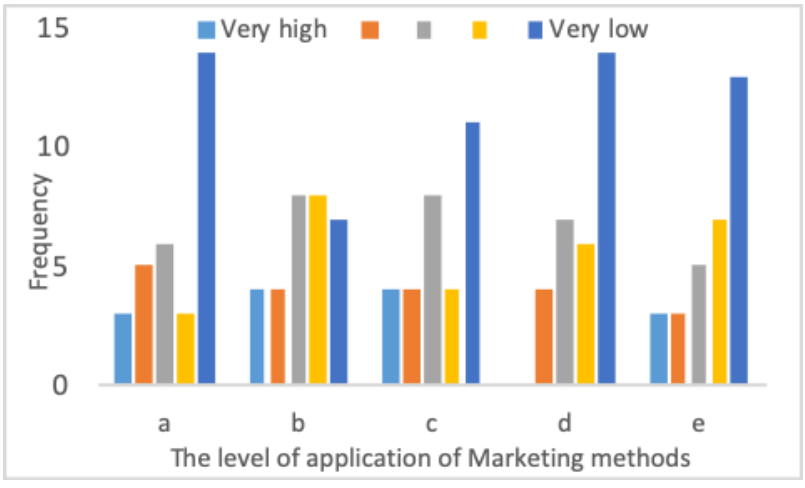

Fig. 1. The level of application of Marketing methods [authors].

Figure 1 depicts the level of use of selected marketing methods in the analyzed companies on a 5point scale where light blue represents a very high level of application, and dark blue represents a very low level of application of selected methods. Subsequently, it was calculated for each Average scale value method (Table 2). For all methods, the Average scale value was above 
level 3, which is a lower level of application of marketing methods. It is positive that companies are customer-centric, as evidenced by the best value in applying marketing mix methods from a customer perspective - 4C (Asv = 3.32) and Customer Relationship Management - CRM (Asv = 3.45). The lowest level of application of marketing methods was in the analysis of marketing environment (Avs $=3.97)$.

Table 2. Marketing methods - Average scale value [authors].

\begin{tabular}{lc}
\hline Marketing method & Average scale value \\
\hline Marketing Mix - 4P & 3.65 \\
Marketing Mix - 4C & 3.32 \\
Customer Relationship Management & 3.45 \\
Marketing Environment & 3.97 \\
Competition analysis & 3.77 \\
\hline
\end{tabular}

Figure 2 depicts the level of use of selected logistics methods in the analyzed companies on a 5-point scale where light blue represents a very high level of application, and dark blue represents a very low level of application of selected methods.

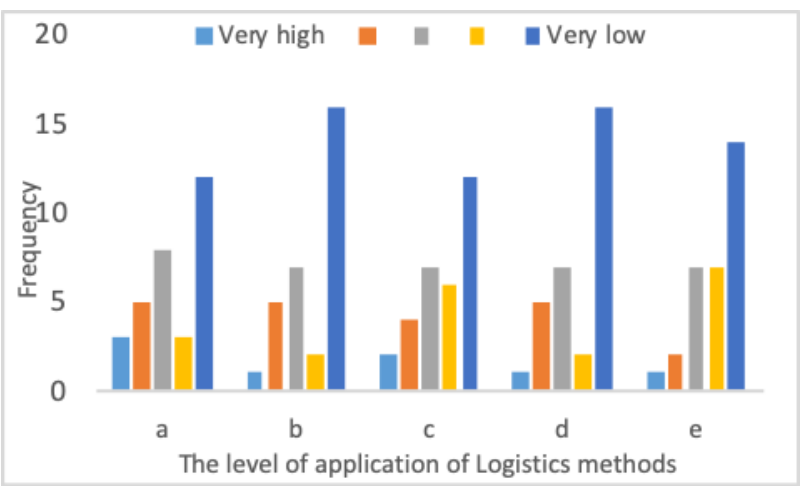

Fig. 2. The level of application of Logistics methods [authors].

Subsequently, it was calculated for each Average scale value method (Table 3). For all methods, the Average scale value was above level 3, which represents a lower level of application of logistics methods.

Table 3. Logistics methods - Average scale value [authors].

\begin{tabular}{lc}
\hline Logistics method & Average scale value \\
\hline Analysis of logistic processes or material flow & 3.52 \\
planning & 3.87 \\
Analyzing the use of workers & 3.71 \\
Material control processes & 3.87 \\
JUST - IN - TIME, Kanban & 4.00 \\
Operational analysis & \\
\hline
\end{tabular}

The highest level of the application was found in the Analysis of logistic processes or material flow planning $($ Asv $=3.52)$. The lowest level was in applying Operational analysis $(\mathrm{Asv}=4.00)$.

\section{Conclusion}

Based on the results of the questionnaire survey, it could be concluded that a relatively low level of application of marketing and logistic methods was found (Average scale value for marketing and logistic methods was higher than 3.50 for most marketing methods and all logistic methods). In order to increase the competitiveness of companies operating in the Czech Republic, companies should strive to improve the level of application of these methods continuously.

The main aim of the paper, to analyze the level of application of selected marketing and logistics methods in different types of companies, has been met. The aim of the paper was not to elaborate a proposal to increase the level of application of these methods with an emphasis on improving the competitiveness of companies doing business in the Czech Republic. Another limitation to mention is that only basic statistical methods are used in the paper. Within the framework of further research, statistical methods will be used to generalize the results.

This research was supported by support research program of Tomas Bata University in Zlín (RVO), and by the Integral Grant Agency, Tomas Bata University in Zlín IGA/FAME/2019/006.

\section{References}

1. P. Kotler, Modern marketing (Grada, Prague, 2007)

2. R. Savitt, Eur. J. Marketing 35, 11/12 (2004)

3. P. Kotler, G. Armstrong, Principles of marketing (Pearson, Boston, 2016)

4. D. M., Scott, The new rules of marketing \& PR: how to use social media, online video, mobile applications, blogs, news releases, and viral marketing to reach buyers directly (Wiley, Hoboken, 2017)

5. A. Kubicka, Found. Manag 8, 1 (2016)

6. V. Chlebovsky, CRM: Customer Relationship Management (Computer Press, Brno, 2005)

7. M. E. Porter, On competition. Updated and expanded (Harvard Business School Publishing, Boston, 2008)

8. M. E. Dobbs, Compet. Rev 24, 1 (2014)

9. M. Jurova, Manufacturing and logistics processes in business (Grada Publishing, Prague, 2016)

10. V. Repa, Business processes: process management and modeling (Grada, Prague, 2007)

11. M. Christopher, Logistics \& supply chain management (Financial Times Prentice Hall, Harlow, 2011)

12. C. S. Kumar, R. Panneerselvam. Manuf. Tech 32, 3 (2007)

13. M. Chovancova, V. Klapita, Open Eng 7, 1 (2017)

14. M. Christopher, H. Peck, Marketing logistics (Routledge, London, 2011) 